\title{
MEMAHAMI SURABAYA DARI KAMPUNG DINOYO
}

\author{
Sarkawi B. Husain ${ }^{1}$
}

\section{Identitas Buku}

Judul : Surabaya, 1945-2010: Neighbourhood, State and Economy in Indonesia's City of Struggle

Penulis : Robbie Peters

Penerbit : : ASAA-NUS Press-nias Press

Tebal :xvii; $254 \mathrm{hlm}$

Tahun Terbit : 2013

\section{Pendahuluan}

Tepat satu dekade setelah Howard Dick menerbitkan bukunya yang berjudul "Surabaya, City of Work: A Socio-economic Histroy, 1900-2000" (2003), akhirnya sebuah buku tentang masyarakat dan kota Surabaya terbit kembali di penghujung tahun 2013. Buku yang berjudul "Surabaya, 1945-2010: Neighbourhood, State, and Economy in Indonesia's City of Struggle" ini ditulis oleh Robbie Peters, seorang antropolog dan dosen di University of Sydney yang sekaligus dapat dikatakan sebagai Indonesianis generasi baru. Pilihannya memilih Surabaya sebagai fokus kajian patut diapresiasi. Sepanjang pengetahuan saya, tidak banyak ilmuan asing yang menaruh perhatian pada Kota Surabaya terutama untuk kajian yang sifatnya komprehensif. Sebelum Robbie Peters, beberapa nama dapat disebut seperti James Peacok (1968), William Frederick (1978; 1986), dan Howard Dick (2003).

"Ketidaktertarikan" sebagian ilmuan asing untuk menjadikan Surabaya sebagai pokok kajian agak mengherankan. Padahal jauh sebelum pemerintah kolonial Belanda menguasai wilayah ini, kota ini telah tumbuh menjadi salah satu kota penting di Nusantara. Menurut Dick, pada abad ke-19 ketika Jawa Timur berkembang dengan ekonomi perkebunannya, Surabaya dengan pelabuhan alamnya menjadi kota terbesar. Pembangunan berbagai infrastruktur seperti rel kereta api, galangan kapal, dan industri, serta penggunaan tenaga uap untuk mesin penggiling tebu, membuat Surabaya berkembang menjadi salah satu kota pelabuhan modern

\footnotetext{
${ }^{1}$ Staf Pengajar Departemen Ilmu Sejarah, Fakultas Ilmu Budaya (FIB) Universitas Airlangga, Email: sarkawihusain@gmail.com
} 
terbesar di Asia, sejajar dengan Calcutta (Kolkata), Rangon (Yangon), Singapura, Bangkok, Hongkong, dan Shanghai Howard Dick (2003).

Surabaya kemudian berkembang semakin maju ketika H.W. Daendels menjadi Gubernur Jenderal Hindia Belanda (5 Januari 1808-15 Mei 1811). Pada masa gubernur jenderal yang ke-36 ini, Surabaya "disulap" menjadi layaknya sebuah kota Eropa kecil. Surabaya dibangun sebagai kota dagang dan kota benteng. Berbagai infrastruktur kota juga dibangun, seperti Jalan Raya Pos (Grote Postweg) yang menghubungkan kota-kota di pantai Utara Pulau Jawa dari Anyer sampai Panarukan (Handinoto, 1996:36-37).

\section{Dari "Perayaan Kematian" hingga PKI}

Kehadiran buku ini penting untuk diapresiasi. Banyak hal yang menarik dari buku ini. Melalui buku ini, Robbie mencoba memahami Surabaya melalui institusiinstitusi yang terdapat dan hidup dalam masyarakat kampung di Dinoyo. Salah satu dari institusi tersebut adalah peringatan atau "perayaan kematian" atau dalam bahasa sehari-hari 'selamatan'. (hlm. 15). Terminologi kampung yang digunakan oleh Peters, dalam konteks Indonesia sulit dipahami, namun penggunaannya yang terus menerus baik dalam publikasi pemerintah maupun dalam karya-karya akademik mengindikasikan bahwa 'kampung' telah memiliki dan terus menjadi sesuatu yang unik. Menurut Colombijn, kampung dapat dipahami sebagai sebuah ruang tertentu, termasuk suara (soundscape) dan bau (smellscape) atau dari bentuk jaringan relasi sosialnya. Sebagai suatu ruang, kampung merupakan suatu unit yang terikat, namun sebagai suatu jaringan sosial, kampung itu tidak tetap dan tak terbatas.

Buku ini terdiri atas sepuluh bagian, yang masing-masing bagiannya dapat dibaca tanpa harus membaca bagian sebelumnya. Salah satu bagian yang sangat menarik adalah ketika Robbie menceritakan tentang Partai Komunis Indonesia (bagian tiga). Pilihan menjadikan topik ini sebagai bagian penting dari buku ini (juga merupakan bagian terbanyak pembahasannya) sangat beralasan. Dalam sejarah kontemporer Surabaya, Partai Komunikasi Indonesia (PKI) tidak hanya menjadi salah satu institusi politik di antara banyak lembaga politik lainnya, tetapi PKI menjadi yang terbesar saat itu dan sangat ekspansif terutama dalam mengahadapi Pemilihan Umum 1955. Hal ini tercermin dalam artikel yang dimuat dalam harian Suara Rakjat, 16/11/1954 berjudul "Surabaja kota merah?". Dalam artikel tersebut disebutkan bahwa di tiap kampung di Kota Surabaya diadakan rapat-rapat propaganda dan penyebaran manifes pemilihan umum PKI dalam bahasa Jawa. Harian tersebut menambahkan bahwa kesibukan propaganda di tiap kampung 
menunjukkan kegiatan yang luar biasa dengan satu tujuan untuk mencapai kemenangan dalam pemilihan umum kelak. Sebuah tujuan yang kemudian terbukti dengan kemenangan PKI dalam Pemilu 1955 di Surabaya. Kampung Dinoyo tentu tidak luput dari upaya propaganda PKI. Dalam acara ceramah serentak PKI di kampung-kampung pada Nopember 1954, Dinoyo dihadiri oleh 400 orang penduduk, terbesar ketiga setelah kampung Bagong Ginajan (900), Wonokitri (900), Karang Redjo (600).

Menurut Robbie Peters, salah satu strategi yang digunakan PKI untuk merebut massa di tingkat bawah adalah pemanfaatan institusi masyarakat dalam hal ini RKKS (Rukun Kampung Kota Surabaya) dan Pemuda Rakyat (hlm. 43). Bahkan dalam sebuah harian disebutkan bahwa RKKS yang didirikan pada tahun 1952 terdapat orang-orang atau pengurus yang sudah punya "nama" dalam peristiwa Madiun dan kembali lagi memegang peranan penting dalam usaha untuk menguasai kota Surabaya. Terdapat peneliti mengatakan bahwa RKKS sengaja dibentuk oleh PKI untuk memudahkan dalam memberi pengaruh pada masyarakat kampung. Akan tetapi, kesimpulan tersebut masih diperdebatkan karena berdasarkan sumber lain disebutkan bahwa RKKS dibentuk oleh masyarakat Surabaya atas inisiatif Walikota Dul Arnowo pada Januari 1952. Pembentukan organisasi kampung tersebut untuk menjembatani aspirasi rakyat dengan pemerintah mengingat Dewan Perwakilan Rakyat Daerah (DPRD) belum terbentuk (Obor Surabaya, 8/1/1952; Pewarta Soerabaia, 12 dan 19/10/1952).

\section{Lebih dari Sekedar Buku Politik}

Tentu saja buku tidak hanya melulu berbicara tentang politik, tetapi juga mengupas dengan baik dan menarik tentang bagaimana masyarakat menghadapai krisis ekonomi yang melanda Indonesia pada tahun 1998 (hlm. 117-139) dan isu keberadaan ninja yang mengiringi krisisi tersebut (hlm. 140-155). Sebagai seorang antropolog, Robbie Peters menghabiskan waktu tidak kurang dari setahun (1998) di kampung Dinoyo, sehingga buku ini dapat juga dikatakan sebagai sejarah kehidupan sehari-hari (daily life history) masyarakat kampung Dinoyo. Kampung Dinoyo memiliki letak yang sangat strategis, dekat dengan beberapa pusat perbelanjaan dan industri besar. Sejak zaman kolonial hingga awal tahun 1970-an, di Ngagel (seberang Kali Mas/Dinoyo) berdiri banyak perusahaan dan pabrik seperti British American Tobacco (BAT), Unilever, Bintang Brewery, Philip-Ralin Light Globe, Barata, dan lain-lain (hlm. 97). Pada tahun 2000-an berdiri sebuah supermarket besar (Carefour) dengan pengunjung yang ramai. Dengan posisi tersebut, Kampung 
Dinoyo menjadi tujuan penting bagi pendatang untuk menjadi bagian dari warganya. Akan tetapi, bagi 'penduduk asli' kampung lama ini menjadi masalah tersendiri, terutama terkait dengan persoalan kriminalitas. Menurut Peters, untuk mengeliminasi masalah tersebut, penduduk mempunyai dua mekanisme atau alat deteksi, yakni kartu keluarga dan selamatan. Dua mekanisme tersebut - kata Peters juga menjadi alat deteksi dan demarkasi antara 'penduduk asli' dan 'penduduk pendatang' (hlm. 213).

Sayang sekali, Robbie Peters tidak menggunakan lebih banyak data tertulis terutama tentang PKI yang tersebar di berbagai koran dan majalah seperti Suara Rakjat, Trompet Masjarakat, majalah Legislatief (antara lain tentang instruksi penyelesaian tahanan PKI), Harian Umum, Sinar Harapan, Antara, majalah Liberty, dan lain-lain. Namun demikian, dengan bahasa yang menarik Robbie Peters berhasil mengetengahkan pada pembaca geliat masyarakat kampung yang sangat dinamis. Tentu buku ini tidak hanya penting bagi antropolog, tetapi juga bagi sejarawan, sosiolog, dan bagi mereka yang tertarik pada kehidupan masyarakat kampung.

\section{Daftar Pustaka}

Dick, H. W. 2002. Surabaya City of Work: A Socioeconomic History, 1900-2000. Athens: Ohio University Press.

Frederick, William H. 1986. Pandangan dan Gejolak: Masyarakat Kota dan Lahirnya Revolusi Indonesia (Surabaya 1926-1946). Jakarta: Gramedia.

Frederick, William H. 1978. Indonesian Urban Society in Transition: Surabaya 1926-1946. An Arbor, MI: Universitu Microfilms International, 1981.

Handinoto, Perkembangan dan Arsitektur Kolonial Belanda di Surabaya 1870-1940. Surabaya: Universitas Kristen PETRA-Andi Press, 1996.

Obor Surabaya, 8/1/1952

Peacok, James. 1968. Rites of Modernization: Symbolic and Social Aspects of Indonesian Proletarian Drama. Chicago: University of Chicago Press.

Pewartas Soerabaia, 12 dan 19/10/1952

Suara Rakjat, 16/11/1954 